\title{
Viral interference between infectious hypodermal and hematopoietic necrosis virus and white spot syndrome virus in Litopenaeus vannamei
}

\author{
Valérie Bonnichon ${ }^{1}$, Donald V. Lightner ${ }^{2}$, Jean-Robert Bonami ${ }^{1, *}$ \\ ${ }^{1}$ Pathogens and Immunity, UMR 5119, CNRS-UM2, cc093, Université Montpellier 2, Place E. Bataillon, \\ 34095 Montpellier Cedex 05, France \\ ${ }^{2}$ Department of Veterinary Science and Microbiology, University of Arizona, 1117 E. Lowell, Tucson, Arizona 85721, USA
}

\begin{abstract}
White spot syndrome virus (WSSV) is highly virulent and has caused significant production losses to the shrimp culture industry over the last decade. Infectious hypodermal and hematopoietic necrosis virus (IHHNV) also infects penaeid shrimp and, while being less important than WSSV, remains a major cause of significant production losses in Litopenaeus vannamei (also called Penaeus vannamei) and L. stylirostris (also called Penaeus stylirostris). These 2 viruses and their interactions were previously investigated in L. stylirostris. We report here laboratory challenge studies carried out to determine if viral interference between IHHNV and WSSV also occurs in L. vannamei, and it was found that experimental infection with IHHNV induced a significant delay in mortality following WSSV challenge. $L$. vannamei infected per os with IHHNV were challenged with WSSV at 0, 10, 20, 30, 40 and $50 \mathrm{~d}$ post-infection. Groups of naïve shrimp infected with WSSV alone died in $3 \mathrm{~d}$ whereas shrimp pre-infected with IHHNV for 30, 40 or $50 \mathrm{~d}$ died in $5 \mathrm{~d}$. Real-time PCR analysis showed that the delay correlated to the IHHNV load and that WSSV challenge induced a decrease in IHHNV load, indicating some form of competition between the 2 viruses.
\end{abstract}

KEY WORDS: White spot syndrome virus · WSSV · Infectious hypodermal and hematopoietic necrosis virus $\cdot \mathrm{IHHNV} \cdot$ Litopenaeus vannamei $\cdot$ Viral interference

\section{INTRODUCTION}

Shrimp viral diseases have been a major cause of commercial shrimp production losses in recent years. Improved understanding of their viral diseases and of their defense system will contribute to the long-term viability of shrimp aquaculture. Crustaceans do not possess the immunoglobulin-based adaptive immune response of vertebrates and host defense is mediated primarily by innate, non-adaptive mechanisms. Such mechanisms involve cellular reactions (e.g. phagocytosis, encapsulation) as well as humoral activities involving the prophenoloxidase-activating cascade and immune-related lysozyme proteins, lectins and antimicrobial peptides (Lee \& Soderhall 2002). Despite the importance of viral diseases for shrimp aquaculture, relatively little is known about antiviral defense mechanisms. Some proteins induced nonspecifically in response to pathogens have been characterized, including a large number of antimicrobial peptides with a broad spectrum of activity for bacteria, fungi and yeast, but their anti-viral effects have rarely been reported (Dupuy et al. 2004).

White spot disease (WSD) due to white spot syndrome virus (WSSV) occurs commonly in shrimp cultured in most regions of the world. In farmed shrimp infected with WSSV, cumulative mortality can reach $100 \%$ within 3 to $10 \mathrm{~d}$ of disease onset (Lightner 1996). 
The first epizootics were reported in Japan in 1993 (Inouye et al. 1994, Momoyama et al. 1994, Nakano et al. 1994) and subsequently elsewhere in Asia. In 1999, the WSD pandemic reached the shrimp farming industries in Central and South America, where the disease caused huge production losses (GAA 1999a,b). Clinical signs included the presence of white spots on the inner surface of the exoskeleton and often a generalized reddish discoloration. WSSV is an enveloped rodshaped virus that contains a circular double-stranded DNA genome of about $305 \mathrm{~kb}$ (Wang et al. 1995, Wongteerasupaya et al. 1995, van Hulten et al. 2001). It was classified recently as the type species of a new genus (Whispovirus) within a new family (Nimaviridae) (Vlak et al. 2004).

Infectious hypodermal and hematopoietic necrosis virus (IHHNV) was recognised in 1981 as the cause of high mortalities in Litopenaeus stylirostris (also called Penaeus stylirostris) (Lightner et al. 1983a,b). IHHNV is a small, icosahedral, non-enveloped virus containing a $4 \mathrm{~kb}$ linear ssDNA genome (Bonami et al. 1990, Mari et al. 1993). In L. vannamei (also called Penaeus vannamei), IHHNV is the causative agent of a disease called 'runt deformity syndrome' (Kalagayan et al. 1991, Lightner 1996) but induced mortalities are low.

Since 2000, anecdotal observations by farmers in Central and South America suggest that infection with IHHNV can confer resistance to WSSV-induced mortalities in Litopenaeus stylirostris and $L$. vannamei. Tang et al. (2003) reported experimental evidence for this phenomenon, demonstrating viral interference between IHHNV and WSSV in L. stylirostris.

In this paper we report viral interference between IHHNV infection and mortalities induced by WSSV challenge in Litopenaeus vannamei. Groups of experimental shrimp pre-infected with IHHNV were challenged with WSSV after intervals of between 10 and $50 \mathrm{~d}$. Mortalities were recorded and quantitative realtime PCR (qPCR) was used to quantify the respective IHHNV and WSSV loads in shrimp tissues. Our data identified interference between the 2 viruses in $L$. vannamei. As resistance to WSSV infection induced by IHHNV also occurs in L. stylirostris (Tang et al. 2003), it may be a general phenomenon in all penaeid shrimp species.

\section{MATERIALS AND METHODS}

Shrimp. Specific pathogen free (SPF) Litopenaeus vannamei (Wyban 1992) were received as $8 \mathrm{~d}$ old postlarvae (PL8) from the Oceanic Institute, Oahu, Hawaii, USA. This stock was reared from PL8 in tanks to an average weight of $3.5 \mathrm{~g}$ using previously described methods (White et al. 1995) before being used in the bioassays. During culture to $3.5 \mathrm{~g}$ and during the bioassays, the experimental shrimp were maintained in aerated artificial seawater at $28^{\circ} \mathrm{C}$ (salinity 25) and fed daily with Rangen $35 \%$ commercial feed pellets (Rangen). At the end of the experiment, shrimp exhibited a mean weight of $5.0 \mathrm{~g}$.

Viral sources. For per os experimental infection, shrimp were fed with tissue from IHHNV-infected Litopenaeus stylirostris carcasses from Hawaii and WSSV-infected Fenneropenaeus chinensis (also called Penaeus chinensis) carcasses from China.

IHHNV infection. For primary infection with IHHNV, 250 Litopenaeus vannamei were maintained in a $1000 \mathrm{l}$ tank and fed once a day for 2 consecutive days with minced IHHNV-infected carcasses at $10 \%$ of their body weight, followed by a pelleted ration of Rangen $35 \%$. To track the development of IHHNV infection, 10 shrimp were randomly sampled every 10 d. Cephalothoraxes were fixed in Davidson's AFA (alcohol-formalin-acetic acid) for histology and in situ hybridization (ISH). Tails were stored at $-20^{\circ} \mathrm{C}$ as a source of DNA for qPCR analysis.

WSSV challenge. To confirm that WSSV-infected tissue would cause lethal infections, a per os challenge was done in parallel using 20 naïve SPF Litopenaeus vannamei, which had not been pre-infected with IHHNV. Shrimp were fed once a day for 2 consecutive days with minced WSSV-infected tissue at $5 \%$ of their body weight, followed by a regular feeding with commercial pellets.

To test the effect of different IHHNV infection levels on subsequent WSSV challenge, at $0,10,20,30,40$ and $50 \mathrm{~d}$ post-IHHNV infection, 20 shrimp were transferred to a $90 \mathrm{l}$ tank and fed for 2 consecutive days with minced WSSV tissue at $5 \%$ of their body weight, followed by a daily feeding with commercial pellets. All moribund and dead shrimp were collected, their heads fixed in Davidson's AFA and their tails stored at $-20^{\circ} \mathrm{C}$ for further analysis. Mortalities were recorded twice a day over a $5 \mathrm{~d}$ period for each bioassay and the 'time to death post-challenge' was determined (Gitterle et al. 2006).

DNA extraction and qPCR. Tail muscle (about $150 \mathrm{mg}$ ) was homogenized in DNAzol reagent (Invitrogen) and clarified by centrifugation at $10000 \mathrm{~g}$ for 10 min. DNA prepared according to the DNAzol protocol was dissolved in $50 \mu \mathrm{l}$ TE buffer $(10 \mathrm{mM}$ Tris- $\mathrm{HCl}$, 1 mM EDTA, pH 8) and stored at $-20^{\circ} \mathrm{C}$. The quality and quantity of DNA were estimated by spectrophotometry at wavelength $254 \mathrm{~nm}$.

qPCR of IHHNV and WSSV DNA levels was performed using methods (primers and probes) described previously (Tang \& Lightner 2001, Durand \& Lightner 2002) to obtain comparable results with the Litopenaeus vannamei and $L$. stylirostris biological mod- 
els. Reactions were performed using a Light Cycler apparatus (Roche) with the Light Cycler Fast Start DNA master $^{\text {plus }}$ hybridization probe kit (Roche). In the reaction, $10 \mathrm{ng}$ DNA was added to a master mix containing $0.3 \mu \mathrm{M}$ each primer and $0.15 \mu \mathrm{M}$ Taq-Man probe in a final volume of $10 \mu \mathrm{l}$. Amplification was performed using the following cycling conditions; $10 \mathrm{~min}$ at $95^{\circ} \mathrm{C}$, followed by 40 cycles of $10 \mathrm{~s}$ at $95^{\circ} \mathrm{C}$ and $30 \mathrm{~s}$ at $60^{\circ} \mathrm{C}$. Each DNA sample was amplified in duplicate.

The number of viral DNA copies in each sample was determined using the Light Cycler fit point method. Serial 10-fold dilutions of plasmid DNA containing cloned PCR fragments spanning the target sequence for the real-time PCR primers were used to generate a standard curve (Tang \& Lightner 2001, Durand \& Lightner 2002). The concentration of each plasmid DNA was determined by $A_{260}$ absorbance values and used to calculate DNA copy numbers with the following formula:

Amount $\left(\right.$ copies $\left.\mu l^{-1}\right)=\frac{\text { Avogadro number } \times \text { concentration }}{M W}$

where concentration is expressed in $\mathrm{g}^{\mathrm{-1}} \mathrm{l}^{-1}$ and molecular weight (MW) in $\mathrm{g} \mathrm{mol}^{-1}$. For the determination of IHHNV load (number of copies $\mu g^{-1}$ of total DNA), its single-stranded DNA structure was taken into account.

Statistical methods. The mean and standard deviation of 'time to death post WSSV-challenge' were calculated for each group. Data were analysed using XLSTAT employing a Kruskal-Wallis 1-way analysis of variance on ranks (non-parametric ANOVA because the normality test failed) to test the effect of IHHNV pre-infection and a Dunnett's (unilateral test) method for all pairwise multiple comparisons. Differences were considered significant at $\mathrm{p}<0.05$ (Saporta 1990). Mean level and standard deviation were calculated for quantification of viral DNA.

\section{RESULTS}

\section{Mortalities among IHHNV-infected Litopenaeus vannamei following WSSV challenge}

No mortalities were observed in the groups of shrimp infected with IHHNV during the experiment (55 d). However, all naïve Litopenaeus vannamei infected with WSSV died by Day 3 post-infection, indicating that the WSSV-infected tissue contained virulent pathogenic virus (Table 1).
After 0, 10, 20, 30, 40 or 50 d post-IHHNV infection, 20 shrimp were challenged with WSSV. Mortality was recorded for $5 \mathrm{~d}$ post-WSSV challenge and the time to death post-WSSV challenge was calculated (Table 1). When co-infected simultaneously (IHHNV 0) with IHHNV and WSSV, all shrimp died by Day 4 postinfection. Shrimp infected with IHHNV for 10 or $20 \mathrm{~d}$ before WSSV challenge also died by Day 3 or 4 . However, after being infected with IHHNV for 30, 40 or $50 \mathrm{~d}$, shrimp died by Day 5 post-WSSV challenge, with relative few mortalities occurring on Days 1 to 3 . The mean time to death post-WSSV challenge in these 3 groups was 4 to $4.4 \mathrm{~d}$ compared to $2.6 \mathrm{~d}$ for the shrimp group challenged with WSSV alone.

Statistical (Kruskal-Wallis) analysis indicated that pre-infection with IHHNV had a significant effect on the time to death post-WSSV challenge ( $p<0.001$ ). The pairwise multiple comparisons (Dunnett's method) indicated that mean times to death postWSSV challenge were significantly higher for shrimp pre-infected with IHHNV for 30, 40 and $50 \mathrm{~d}$ compared to the positive control group or pre-infection for 10 to $20 \mathrm{~d}$.

Histology and ISH confirmed that the moribund and dead shrimp sampled were co-infected with both viruses for the groups challenged with WSSV on Day $20,30,40$ or 50 after pre-infection with IHHNV (5 shrimp analyzed for each time point). For groups challenged with WSSV at Day 0 and 10, IHHNV loads were too low to be detected by ISH (data not shown).

\section{Virus infection levels}

IHHNV load (expressed in viral DNA copies $\mu^{-1}$ total DNA) in 10 randomly sampled experimental shrimp was monitored by qPCR at $10 \mathrm{~d}$ intervals postinfection. Virus load generally increased over the $50 \mathrm{~d}$ post-infection period and peaked at Day 40 with an average IHHNV-DNA load of $2.6 \times 10^{9}$ copies ${\mu g^{-1}}^{-1}$ total DNA (Fig. 1A). 

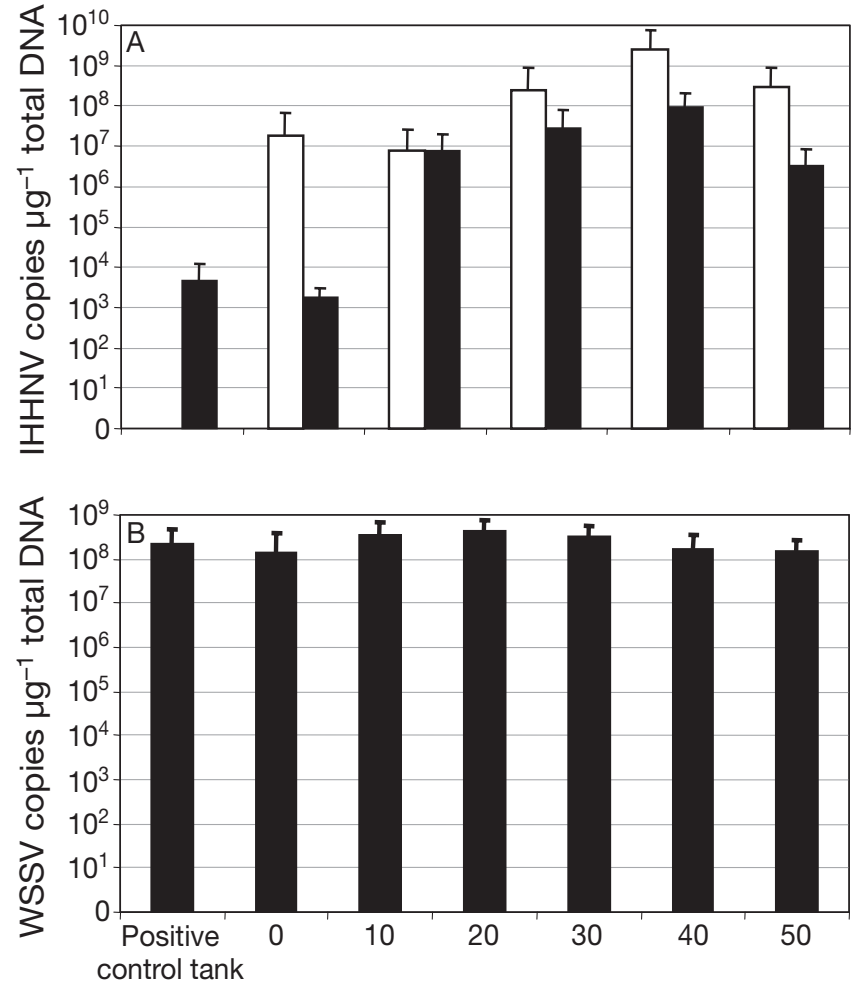

Incubation period post-IHHNV infection (d)

Fig. 1. Litopenaeus vannamei. Viral loads (mean $+\mathrm{SD})$ determined by quantitative real-time PCR (qPCR). (A) IHHNVDNA copy number detected during infection course (white bars); shrimp $(\mathrm{n}=10)$ were tested every $10 \mathrm{~d}$ after IHHNV exposure. IHHNV-DNA copy number detected in moribund and dead shrimp $(6 \leq \mathrm{n} \leq 9)$ infected with IHHNV and subsequently challenged with WSSV (black bars). (B) WSSVDNA copy number detected in moribund and dead shrimp $(6<\mathrm{n}<10)$ infected with WSSV, either alone (positive control) or following primary infection and incubation with IHHNV

After WSSV challenge, WSSV and IHHNV DNA loads in all moribund and dead shrimp $(6<\mathrm{n}<10$ for each group) were determined by qPCR. IHHNV levels in shrimp pre-infected with IHHNV for various durations and challenged with WSSV were lower than in IHHNV-infected shrimp not challenged with WSSV (Fig. 1A). For example, IHHNV DNA loads of $2.5 \times 10^{8}$ and $2.6 \times 10^{9}$ copies $\mu^{-1}$ of total DNA were found in shrimp at 30 and $40 \mathrm{~d}$ (respectively) post-IHHNV infection, while $2.7 \times 10^{7}$ and $9.7 \times 10^{7}$ copies $\mu g^{-1}$ total DNA were found at the same time points in moribund or dead IHHNV-infected shrimp sampled following challenge with WSSV (i.e. 10- to 30-fold lower after WSSV challenge).

For bioassays with the highest mean time to death values (i.e. from Days 30, 40 and 50 post-IHHNV infection) (Table 1), IHHNV-DNA load prior to WSSV-challenge $\left(3.0 \times 10^{8}\right.$ to $2.6 \times 10^{9}$ copies $\mu^{-1}$ of total DNA) was higher than on Days 10 and 20 post-infection $\left(<10^{8}\right.$ copies $\mu^{-1}$ of total DNA). The average IHHNVDNA load detected in moribund and dead shrimp after WSSV challenge increased with the duration of IHHNV infection, reaching $9.8 \times 10^{7}$ copies ${\mu g^{-1}}^{-1}$ of total DNA after $40 \mathrm{~d}$, but dropped at $50 \mathrm{~d}$ post-IHHNV infection (Fig. 1A).

For the WSSV-positive control tank (not pre-infected with IHHNV), qPCR detected an average WSSV-DNA

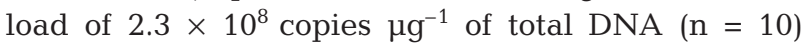
(Fig. 1B). For WSSV-challenged shrimp pre-infected with IHHNV (0-50 d), qPCR identified an average WSSV-DNA load of $1.4 \times 10^{8}$ to $4.3 \times 10^{8}$ copies $\mu^{-1}$ of total DNA, which was in the same range detected in moribund or dead shrimp from the WSSV-positive control tank (Fig. 1B).

\section{DISCUSSION}

We have showed here that IHHNV infection can induce delayed mortality in Litopenaeus vannamei following per os challenge with WSSV. This phenomenon likely involves viral interference, mediated either by intracellular process or by anti-viral molecules induced by IHHNV infection. Viral interference, in which one virus interferes with or induces resistance to subsequent infection by another virus, can be induced by a variety of mechanisms (Chinchar et al. 1998, Youngner \& Whitaker-Dowling 1999). For example, infection with one virus may block entry of another virus by down-regulating production of cellular receptors or through competition for a common receptor. Alternatively, an existing viral infection can shutdown host cell functions required for replication of a second virus. In shrimp, it is also possible that innate anti-viral factors released into haemolymph could interfere with subsequent infection by another virus.

Data obtained here indicate that the delay in WSSVinduced mortality was affected by the duration of IHHNV infection. Moreover, qPCR analysis showed that this delay was related to IHHNV load. The most significant delay in WSSV-induced mortality in shrimp corresponded to the highest average in IHHNV load (Day $40,2.6 \times 10^{9}$ copies $\mu^{-1}$ of total DNA) (Table 1 , Fig. 1A). Moreover, statistical analysis showed a significant delay in mortality, with the highest mean time to death, when IHHNV-DNA level was higher than $10^{8}$

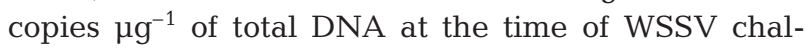
lenge.

Age and size of experimental animals could potentially interfere with mortality induced by WSSV challenge. However, because no such age-size effects have been reported for any species of penaeid, shrimp juveniles between 3.5 and $5.0 \mathrm{~g}$ were used in this study. A previous study has shown that IHHNV pre-infection 
can induce resistance to WSSV in Litopenaeus stylirostris (Tang et al. 2003). Differences with our results and those reported for IHHNV-induced resistance to WSSV in L. stylirostris could be attributed to differences in infection levels or in shrimp sensitivity to viral infection. Indeed, in L. stylirostris, an IHHNV load of $3.0 \times 10^{9}$ copies $\mu^{-1}$ of total DNA was detected in shrimp that survived WSSV challenge, which is almost 30 -fold greater than we detected in moribund or dead L. vannamei $\left(10^{8}\right.$ copies $\mu \mathrm{g}^{-1}$ of total DNA) sampled in the present study. Moreover, the WSSV load (about $10^{7}$

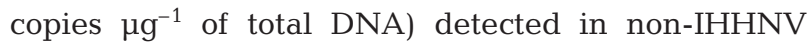
infected L. stylirostris (Tang et al. 2003), was about 10fold lower than we detected in $L$. vannamei (about $10^{8}$ copies $\mu^{-1}$ of total DNA). Due to the importance of infection levels in this phenomenon, these differences in virus loads in $L$. stylirostris and $L$. vannamei could explain the delayed mortality in $L$. vannamei, but without the expected reduction in mortalities due to WSSV infection in our bioassays. Nonetheless, our data indicate some competitive exclusion relationship (Gause 1934, De Boer \& Perelson 1994) between IHHNV and WSSV, which supports the hypothesis of a possible common cellular receptor or shared cellular replication machinery.

WSSV challenge resulted in a reduction in IHHNVDNA load in Litopenaeus vannamei. When preinfected with IHHNV $40 \mathrm{~d}, 2.6 \times 10^{9}$ IHHNV-DNA copies $\mu^{-1}$ of total DNA were detected before WSSV challenge and only $9.7 \times 10^{7}$ copies in moribund or dead shrimp infected with IHHNV $40 \mathrm{~d}$ and challenged with WSSV. This decrease seems to confirm our previous hypothesis of a competitive reaction between the 2 viruses rather than DNA degradation between death and sampling of the animals.

Another possible explanation for the observed delay in WSSV-induced mortality is the production of antiviral molecules associated with the innate nonspecific defence response. In this case, the correlation between IHHNV infection level and delay of WSSVinduced mortality in Litopenaeus vannamei, or resistance to WSSV in L. stylirostris (Tang et al. 2003), suggests that such molecules increase in proportion to the IHHNV load. A similar 'quasi-immune' response to WSSV has been reported in Marsupenaeus japonicus (also called Penaeus japonicus) (Venegas et al. 2000), in which resistance was linked to the appearance of a virus neutralising factor in the haemolymph of 'immune' shrimp (Wu et al. 2000). The rapid rate of WSSV-induced mortality we observed in $L$. vannamei might have limited the effect of such an anti-viral factor. Further studies are needed to identify the mechanism by which a primary viral infection (IHHNV) of L. vannamei delays the onset of WSSVinduced mortalities.
Acknowledgements. This work was supported by the European Commission through the AVINSI program (Contract no. QLK2-CT-2002-01691). V.B. thanks all the members of the Aquaculture Pathology Laboratory, University of Arizona, for their helpful assistance during her stay in Tucson.

\section{LITERATURE CITED}

Bonami JR, Trumper B, Mari J, Bréhelin M, Lightner DV (1990) Purification and characterization of the infectious hypodermal and hematopoietic necrosis virus of penaeid shrimps. J Gen Virol 71:2657-64

Chinchar VG, Logue O, Antao A, Chinchar GD. (1998) Channel catfish reovirus (CRV) inhibits replication of channel catfish herpesvirus (CCV) by two distinct mechanisms: viral interference and induction of an anti-viral factor. Dis Aquat Org 33:77-85

De Boer RJ, Perelson AS (1994) T cell repertoires and competitive exclusion. J Theor Biol 169:375-390

Dupuy JW, Bonami JR, Roch P (2004) A synthetic antibacterial peptide from Mytilus galloprovincialis reduces mortality due to white spot syndrome virus in palaemonid shrimp. J Fish Dis 27:57-64

Durand S, Lightner DV (2002) Quantitative real-time PCR for the measurement of white spot syndrome virus in shrimp. J Fish Dis 25:381-389

GAA (Global Aquaculture Alliance) (1999a) Shrimp white spot virus confirmed in Central America. GAA Newsletter Vol 2(2), Global Aquaculture Alliance, St. Louis, MO

GAA (Global Aquaculture Alliance) (1999b) Shrimp white spot disease in Latin America - an update. GAA Newsletter Vol 2(3), Global Aquaculture Alliance, St. Louis, MO

Gause GF (1934) The struggle for existence. Williams and Wilkins, Baltimore, MD

Gitterle T, Ødegård J, Gjerde B, Rye M, Salte R (2006) Genetic parameters and accuracy of selection for resistance to white spot syndrome virus (WSSV) in Penaeus (Litopenaeus) vannamei using different statistical models. Aquaculture 251:210-218

Inouye $\mathrm{K}$, Miwa $\mathrm{S}$, Oseko $\mathrm{N}$, Nakano $\mathrm{H}$, Kimura $\mathrm{T}$, Momoyama K, Hiraoka M (1994) Mass mortalities of cultured kuruma shrimp, Penaeus japonicus, in Japan in 1993: electron microscopic evidence of the causative virus. Fish Pathol 29:149-158

Kalagayan G, Godin D, Kanna R, Hagino G, Sweeney J, Wyban J, Brock J (1991) IHHN virus as an etiological factor in runt-deformity syndrome of juvenile Penaeus vannamei cultured in Hawaii. J World Aquacult Soc 22:235-243

Lee SY, Soderhall K (2002) Early events in crustacean innate immunity. Fish Shellfish Immunol 12(5):421-37

Lightner DV (1996) A handbook of shrimp pathology and diagnostic procedure for diseases of cultured penaeid shrimp. World Aquaculture Society, Baton Rouge, LA

Lightner DV, Redman RM, Bell TA (1983a) Infectious hypodermal and hematopoietic necrosis, a newly recognized virus disease of penaeid shrimp. J Invertebr Pathol 42:62-70

Lightner DV, Redman RM, Bell TA, Brock JA (1983b) Detection of IHHN virus in Penaeus stylirostris and $P$. vannamei imported into Hawaii. J World Maricult Soc 14:212-225

Mari J, Bonami JR, Lightner DV (1993) Partial cloning of the genome of infectious hypodermal and hematopoietic necrosis virus, an unusual parvovirus pathogenic for penaeid shrimps; diagnosis of the disease using a specific probe. J Gen Virol 74:2637-2643 
Momoyama K, Hiraoka M, Nakano H, Koube H, Inouye K, Oseko N (1994) Mass mortalities of cultured kuruma shrimp, Penaeus japonicus, in Japan in 1993: histopathological study. Fish Pathol 29:141-148

Nakano H, Koube H, Umezawa S, Momoyama K, Hiraoka M, Inouye K, Oseko S (1994) Mass mortalities of cultured kuruma shrimp, Penaeus japonicus, in Japan in 1993: epizootiological survey and infection trials. Fish Pathol 29:135-139

Saporta G (1990). Probabilités, analyse de données et statistique. Editions Technip, Paris

Tang KF, DV Lightner (2001) Detection and quantification of infectious hypodermal and hematopoietic necrosis virus in penaeid shrimp by real-time PCR. Dis Aquat Org 44:79-85

Tang KF, Durand SV, White BL, Redman RM, Mohney LL, Lightner DV (2003) Induced resistance to white spot syndrome virus infection in Penaeus stylirostris through pre-infection with infectious hypodermal and hematopoietic necrosis virus - a preliminary study. Aquaculture 216:19-29

Van Hulten MC, Witteveldt J, Peters S, Kloosterboer N and 5 others (2001) The white spot syndrome virus DNA genome sequence. Virology 286:7-22

Venegas CA, Nonaka L, Mushiake K, Nishizawa T, Murog K (2000) Quasi-immune response of Penaeus japonicus to penaeid rod-shaped DNA virus (PRDV). Dis Aquat Org 42:83-89

Vlak JM, Bonami JR, Flegel TW, Kou GH, Lightner DV, Loh

Editorial responsibility: Timothy Flegel,

Bangkok, Thailand
CF, Loh PC, Walker PJ (2004) Nimaviridae. In: Fauquet CM, Mayo MA, Maniloff J, Desselberger U, Ball LA (eds) VIIIth Report of the International Committee on Taxonomy of Viruses. Elsevier, London, p 187-192

Wang $\mathrm{CH}$, Lo $\mathrm{CF}$, Leu JH, Chou CM and 6 others (1995) Purification and genomic analysis of baculovirus associated with white spot syndrome (WSBS) of Penaeus monodon. Dis Aquat Org 23:239-242

White BL, Schofield PJ, Poulos BT, Lightner DV (2002) A laboratory challenge method for estimating Taura Syndrome virus resistance in selected lines of Pacific white shrimp Litopenaeus vannamei. J World Aquacult Soc 33:341-348

Wongteerasupaya C, Vickers JE, Sriurairatana S, Nash GL and 6 others (1995) A non-occluded, systemic baculovirus that occurs in cells of ectodermal and mesodermal origin and causes high mortality in the black tiger prawn Penaeus monodon. Dis Aquat Org 21:69-77

Wu JL, Nishioka T, Mori K, Nishizawa T, Muroga K (2000) A time-course study on the resistance of Penaeus japonicus induced by artificial infection with white spot syndrome virus. Fish Shellfish Immunol 13:337-403

Wyban JA (1992) Selective breeding of specific pathogen-free (SPF) shrimp for high health and increased growth. In: Fulks W, Main KL (eds) Diseases of cultured penaeid shrimp in Asia and the United States. The Oceanic Institute, Honolulu, HI, p 257-268

Youngner JS, Whitaker-Dowling P (1999) Interference. In: Granoff A, Webster RG (eds) Encyclopedia of virology, 2nd edn. Academic Press, San Diego, CA, p 850-854

Submitted: December 1, 2005; Accepted: June 15, 2006 Proofs received from author(s): September 11, 2006 